\title{
SUSTAINABLE INTENSIFICATION OF MODERN AGRICULTURE THROUGH PRODUCTION TECHNOLOGIES ON DIFFERENT READINESS LEVELS
}

\author{
Mariusz MACIEJCZAK ${ }^{1}$, Janis FALTMANN ${ }^{2}$ \\ ${ }^{1}$ Warsaw University of Life Sciences, POLAND \\ ${ }^{2}$ University of Hohenheim, GERMANY \\ E-mail of corresponding author: mariusz_maciejczak@sggw.pl
}

Key words: agriculture, technologies, sustainable intensification, technology readiness, market readiness

\begin{abstract}
The modern agricultural production is facing the problem of a growing society as well as different environmental threats. To solve this issue, agricultural production should be more sustainable and efficient which can be reached by using new technologies. In the paper the most important technologies, which were evaluated to find how and when they could be used for a sustainable intensification of agriculture were highlighted by applying technology and market readiness models. It was found that technologies that collect or utilize advanced data (sensors, drones) are more applicable for use, contrary to nanotechnologies where the costs of development and applications limits the readiness.
\end{abstract}

\section{INTRODUCTION}

Agriculture is a major area of human activity affecting both its safety and well-being and the environment in which it lives. It thus becomes the primary factor conditioning global changes. Agriculture should be treated as a complex system with inherent adaptive abilities (Maciejczak, 2017). The complexity of agriculture is the result of the interplay of its individual elements as well as the interconnections of elements throughout the system and between the system and its surroundings. Over the centuries the economic pressures have led to systemic domination of agriculture based on the mechanisms of commercialization, concentration, specialization, agrarian structural change and capital-intensive intensification. Such actions have led to the imbalance in both the natural and the social systems interacting with agriculture. Currently, agriculture is facing many problems, i.e. the need for the increase of food production by $60-110 \%$ by 2050 due to the population growth while ensuring at the same time the protection of the environment under the sustainability demand (Foley at al., 2005). In order to face these issues, the dominating concept of quantitative (solely economic) growth is being replaced by the approach of the development based on the qualitative more sustainable nature. Tittonell (2014) postulates adaptation actions within the complex agricultural system, based on strategies for further intensification, however based on the sustainable assumptions. This could be induced in a number of different ways with only the two most effective ones being pointed out here. The first is called industrial intensification and aims to maintain the industrial path based on innovation in the technological and organizational sphere. The second named as agro-ecological intensification is focusing on the intensification of more targeted agro-ecosystems, the use of more production-friendly technologies that provide better harmonization of production and environmental objectives. The future prospect of modern industrialized agricultural systems is being challenged on several fronts because of its dependence on capital, external energy and agrochemical inputs, and for its adverse impact on biodiversity and on human health (Struik et al., 2014).

Regardless of the strategic options of sustainable intensification, this concept requires application of innovative technologies. However, these technologies of modern agriculture are in different stages of development and use. This significantly influences 
the dynamics of changes in agriculture. Therefore, the main objectives of the paper are threefold. Firstly, the paper aims to present, based on literature review, the needs and solutions for innovative technologies which are most promising for further development of modern model of sustainably intensive agriculture. Secondly, using the foresight approach, it aims to assess the technology and market readiness levels of selected technologies. Finally, based on experts' opinion, it will provide the recommendations for development and diffusion of the most perspective technologies.

\section{MATERIALS AND METHODS}

This paper uses different methodologies selected to correspond best to the goals set. The investigations are based on primary and secondary data sources. Firstly, the literature review of scientific papers was performed. Using different key words, based on abstract review, there were selected 79 papers, which later, after full text analysis, were reduced to 17 . Based on the review 10 most promising technologies were selected, 6 from crop production and 4 from animal production. The primary data comes from the Real-Time Delphi survey. The rationale for the choice of the foresight heuristic Delphi method was more the hypothetical then empirical impact of selected technologies for modern agriculture. There was used Real-Time Delphi approach (Grisham, 2009). Using a webbased tool a qualitative and quantitative survey was held. The questionnaire was open from 1st May 2017 to 31st August 2017. There were identified 10 experts from two countries: Poland and Germany. From each country participated 5 experts being: farmers, technology developers and traders, consumers, policy makers and academics. All experts were chosen deliberately because of their knowledge about agriculture and its technological advancement. There was a basic assumption about possible application and impact of assessed technology in mit-term perspective of 2025 having in mind the needs of sustainable development. Two scales of Technology Readiness Level (TRL) and Market Readiness Level (MRL) were applied. TRL enables the assessment of the maturity of a particular technology and the consistent comparison of maturity between different types of technologies. It is based on a scale from 1 to 9 , with 9 being the most mature technology (EARTO, 2011). MRL enables the assessment of the readiness of technology for commercialisation and diffusion. It is based on a scale from 1 to 5, with 5 being the most marketable (Aasrud et al., 2010). To analyse linkages between TRL and MRL the rho-Spearman correlation test was used (Parlińska and Parliński, 2011).

\section{RESULTS AND DISCUSSION}

Modernisation in agriculture is a very relative concept (ILO, 1991). It differs very much depending on the country, the region as well as on individual farm perspective. Many factors are associated with the progress made due to implementation of new techniques, technology or other innovative solutions. Therefore, for the purpose of this research, the framework for the concept of the modernization of agriculture will be established. The analysis is limited to the European perspective with the focus on developed farms which are considered as enterprises. For such farms, implementation of innovations, esp. in forms of new technologies is attached to the umbrella approach of precision agriculture. It is a farming management concept based on observing, measuring and responding to inter and intra-field variability in crops, or to aspects of animal rearing (Takacs-Gyorgy et al., 2014). The benefits to be obtained are chiefly due to increased yields and/or increased profitability of production to the farmer. Other benefits are better working conditions, increased animal welfare and the potential to improve various aspects of 
environmental stewardship. As stressed by (Weiss, 1996) the implementation of precision farming has become possible as a result of the development of innovative technologies i.e. sensors, or drones combined with procedures to link mapped variables to appropriate farming practices such as tillage, seeding, fertilization, herbicide and pesticide application, harvesting and animal husbandry. Subsequently, it is relying on automatic monitoring of individual animals and is used to monitor animal behaviour, welfare and productivity as well as their physical environment. Advances in nanotechnologies could also be implemented in a wide spectrum i.e. for health maintenance of both animals and plants. Nevertheless, one needs to remember that the adoption of this concept encounters specific challenges not only due to the size and diversity of farm structures but also due to the readiness of available technologies to meet high demands of technological, economic, social and environmental efficiency. The detailed literature review enabled us to distinguish 10 technologies that could contribute the most to the development of precision agriculture (table 1).

Table 1. Top 10 technologies of future sustainable agriculture - a literature review

\begin{tabular}{|l|l|l|}
\hline Technology & Description & Authors \\
\hline CROP PRODUCTION & $\begin{array}{l}\text { Use nanotechnology for disease control in crop } \\
\text { production. }\end{array}$ & $\begin{array}{l}\text { Fraceto et al., 2016, } \\
\text { Kuzma \& VerHage, 2006 }\end{array}$ \\
\hline -NOLOGY & $\begin{array}{l}\text { Use all the data that is collected from guidance system to } \\
\text { get an overview over your work and in- and output. }\end{array}$ & $\begin{array}{l}\text { Takacs-Gyorgy et al., } \\
\text { 2013, Francik, 2010 }\end{array}$ \\
\hline SOIL & $\begin{array}{l}\text { Use tractor mounted sensors to get information about the } \\
\text { nitrogen in the soil to control the fertilizer use. }\end{array}$ & $\begin{array}{l}\text { Frewer et al. 2011, } \\
\text { Sanders and Masri, 2016 }\end{array}$ \\
\hline DRONES & $\begin{array}{l}\text { Use drones to analyse e.g. the chlorophyll content of the } \\
\text { crops to use fertilizer or pesticides more precisely. }\end{array}$ & $\begin{array}{l}\text { Gozdowski et al., 2010, } \\
\text { Dukaczewski } \\
\text { Bielecka, 2009 }\end{array}$ \\
\hline SENSORS & $\begin{array}{l}\text { Get more sensors connected through new and cheaper } \\
\text { systems than SIM Cards. }\end{array}$ & $\begin{array}{l}\text { Jensen et al., 2012, } \\
\text { Ojha et al. 2015 }\end{array}$ \\
\hline AUTONOMY & $\begin{array}{l}\text { Use fully autonomous tractors to reduce labour costs and } \\
\text { work more efficiently. }\end{array}$ & $\begin{array}{l}\text { Dukaczewski } \\
\text { Bielecka, 2009; Xiweia } \\
\text { and Xiangdong, 2007 }\end{array}$ \\
\hline ANIMAL PRODUCTION & $\begin{array}{l}\text { Use smart devices like electronic earmarks to get } \\
\text { information about the position and health of animals. }\end{array}$ & $\begin{array}{l}\text { English et al., 2013, } \\
\text { Cupiał et al., 2015 }\end{array}$ \\
\hline DEVICES & $\begin{array}{l}\text { Use on-time software to get recent information about e.g. } \\
\text { the feeding behaviour of your animals. }\end{array}$ & $\begin{array}{l}\text { Tyler and Griffin, 2016, } \\
\text { Cupiał et al., 2015 }\end{array}$ \\
\hline DATA & $\begin{array}{l}\text { Use nanotechnology to make more precise diagnoses as } \\
\text { well as creating smart medicine. }\end{array}$ & $\begin{array}{l}\text { Parisi et al., 2014, } \\
\text { Głód et al., 2014 }\end{array}$ \\
\hline $\begin{array}{l}\text { NANe more sensors to monitor and control different } \\
\text {-NOLOGY }\end{array}$ & $\begin{array}{l}\text { Kopiński 2014, Ojha et } \\
\text { al., 2015 }\end{array}$ \\
\hline SENSORS & \begin{tabular}{l} 
ariables of the digestion and wellbeing of the animals. \\
\hline
\end{tabular} &
\end{tabular}

Source: own research based on the literature review

The Delphi results of the technological and market readiness levels of selected technologies (fig. 1 and 2) showed for both perspectives similar results. Also, the calculated rho-Spearman correlation between TRL and MRL confirmed a strong correlation on the level of $0.933(\mathrm{r}<0.001)$. It means that the market readiness is closely associated with the technological readiness. The more technology is prepared to be implemented on the market the more market is creating conditions for its release. With this respect, the majority of experts agreed also on the importance of knowledge, which could be considered as a fourth dimension of market readiness. The farmers need to know how the technology works and what the benefits of its use are, not on experimental fields, but in other farms. 


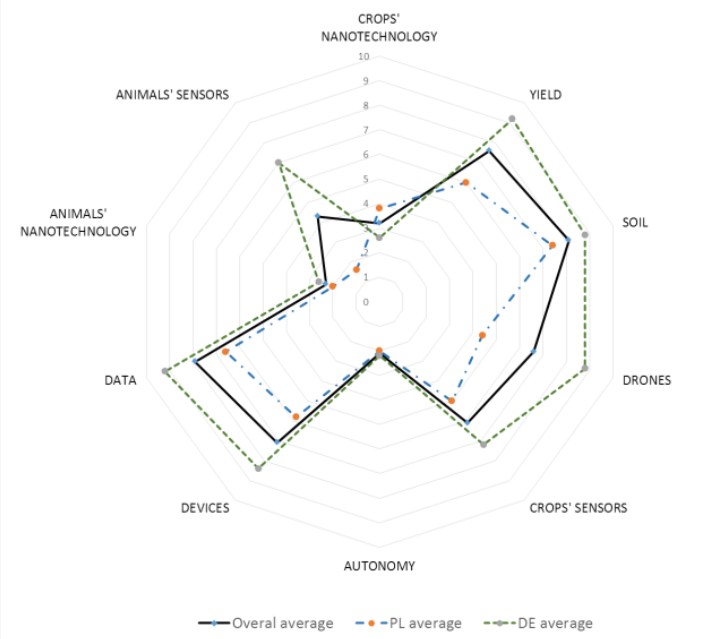

Fig. 1. Technology Readiness Level of analysed technologies. Source: own investigation

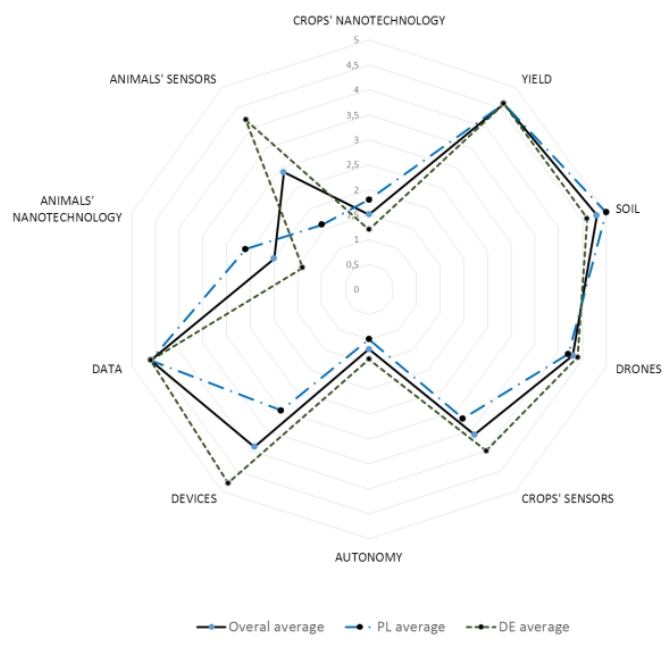

Fig. 2. Market Readiness Level of analysed technologies. Source: own investigation

The analysis and evaluation of the different opinions of the experts showed that there are many similarities as well as differences in the way Polish and German experts are seeing the market and technology readiness of the chosen technologies. The average value for nanotechnology in crop production in terms of technology readiness was 3.2. This is a quite low value. The German experts saw an average TRL at 2.6 and the Polish experts at 3.8. The market readiness was on average also very low (1.5). With 1.8 the Polish experts were more optimistic with this technology while the German experts saw it at a low value of 1.2. The most common opinion was that Nanotechnology is an interesting technology but application will need more time and a high investment. Some experts were not optimistic at all but this is often the case when talking about technologies of the far future. Collecting data from your guidance system is far readier in terms of technology and market readiness. With an overall average TRL of 7.6 and 9.2 in Germany and 6 in Poland and an average MRL of 4.6 in general, in Poland and Germany the technology is already adopted in those countries. From German experts, there were concerns about the user-friendliness of the product. In Poland, this technology is just used by big farms which means that there is some space for development. Beside data collection, soil analysis was also a technology that was ranked highly in terms of readiness levels. The average values for TRL were 8.1 overall, 7,4 for Poland and 8.8 for Germany. The values for MRL were 4.8 in general, 5 in Poland and 4.6 in Germany. This technology is also already adopted to the market and needs some improvements in terms of costs so that also small farmers can use it. Drones had average values more in the middle field (6.6). What was interesting is that the TRL for Germany (8.8) and Poland (4.4) were quite different. The same occurred for the MRL where the average for all was 4.1, for Poland 3.8 and for Germany 4.4. The German experts were still not happy about the costs. Furthermore, experts argued that the technology is not useful due to the fact, that modern satellite pictures could bring the same information. The Polish experts were really sure that this technology will help to become more sustainable. Sensors left also some room between both experts. In general, the TRL was 6,1 while the value in Germany was 7.2 and in Poland 5. The market readiness was in average 3.5 and in Poland 3 and Germany 4. The opinion of the Polish experts was really positive on that technology. The opinions of the German experts 
were also positive. One expert said that the technology will only be important if a farmer uses a completely automatic system.

With autonomy in crop production, that last technology was a big topic of the future. The TRL in general was 2.1 in Germany 2.2 and in Poland 2. The MRL was low as well. In average, it was 1.4 in Germany 1 and in Poland 1. The biggest problem from German experts were the legal issues while the Polish experts argued more that autonomy will just be a topic of some niches. In animal production, the devices got an average TRL of 7.1. The value for Poland was 5.8 and the value for Germany 8.4. The MRL was 3.9 in average, 3 in Poland and 4.8 in Germany. Here you can see again big differences. The Polish and German concerns are that this technology is too expensive to be adopted. For data analyses in animal production the values of TRL are also different. In average, it is 7.9 while for Poland it is 6,6 and for Germany 9.2. The MRL is in both cases 4.6. In Germany, the technology should be better developed in terms of usability. The Polish doubts are connected with the farmers' knowledge for using this technology. Nanotechnology in animal production seems to be again a technology that will be more interesting in far future. Thus, it gets low values of TRL (overall average 2.3, Germany 2.6 and Poland 2) and MRL (overall 2, Poland 2.6 and Germany 1.4). It is interesting that those values are lower than the values for Nanotechnology in crop production. The argumentation was in part the same, but it seems that the experts are more comfortable to use this technology with crops than with animals. The last technology was sensors in animal production. The average value for TRL was 4,3 while Germany was really high with 7 and Poland really low with 1.6. The MRL was in average 2.8 while in Poland 1.4 and in Germany 4.2. The Polish experts are seeing many problems in the difficulty of measuring the values. German experts were more optimistic, due to the fact that sensors are getting cheaper. One key of this technology is that the data should be made usable.

\section{CONCLUSION}

The conducted research confirmed that development of modern model of agriculture requires strategic options based on sustainability approach applied similarly and comprehensively on the intensification concept. This could be obtained and driven by the application of modern technologies. These technologies have a great potential to provide benefits of sustainable values. It was proved, however that the technologies that could bring these values are on different technological readiness and thus its market readiness is also different. The highest TRL and MRL results showed technologies that collect (i.e. sensors or drones) or use (soil or yield management systems) of data. The lowest results were obtained with very advanced technologies connected to nanomaterials. This suggest that for sustainable management of modern agriculture the more detailed data are needed and the more technology is fulfilling this requirement for knowledge building the bigger its readiness and diffusion. On other hand nanotechnologies, which development is very expensive are very promising, but in midterm perspective they application due to the costs and efficiency is limited.

\section{BIBLIOGRAPHY}

Aasrud A., Baron R. and Karousakis K. (2010). Market readiness: building blocks for market approaches. Organisation for Economic Co-operation and Development, 7-21

Cupiał M., Szeląg-Sikora A., Niemiec M. (2015). Optimisation of the machinery park with the use of OTR-7 software in context of sustainable agriculture. Agriculture and Agricultural Science Procedia $7(2015), 64-69$ 
Dukaczewski D., Bielecka E. (2009). Nowe teledetekcyjne misje satelitarne i możliwości wykorzystania ich wyników do zasilania baz danych przestrzennych. Roczniki Geomatyki, T. VII, Z. 5(35), 41-54.

EARTO - European Association of Research and Technology Organisations (2014). The TRL Scale as a Research \& Innovation Policy Tool, EARTO Recommendations. Brussels.

English A., Ball D., Ross P., Upcroft B., Wyeth G., Corke P. (2013). Low Cost Localisation for Agricultural Robotics. Proceedings of Australasian Conference on Robotics and Automation, 2-4 Dec 2013, University of New South Wales, Sydney Australia.

Foley, J.A., R. DeFries, G.P. Asner, C. Barford, G. Bonan, S.R., Carpenter, F.S. Chapin, M.T. Coe, et al. (2005). Global consequences of land use. Science 309, 570-574.

Fraceto L., Grillo R., Medeiros G.A., Scognamiglio V., Bartolucci C. (2016). Nanotechnology in Agriculture: Which Innovation Potential Does It Have? Front. Environ. Sci. 4: 20, 1-5

Francik, S. (2010). Analiza wykorzystania przez rolników programów komputerowych do wspomagania decyzji. Inżynieria Rolnicza, 7(125), 47-54.

Frewer L.J., Bergmann K., Brennan M., Lion R., Meertens R., Rowe G. et al. (2011). Consumer response to novel agri-food technologies: implications for predicting consumer acceptance of emerging food technologies. Trends in Food Science \& Technology 2011, 22(8), 442-456.

Głód D., Adamczak M., Bednarski W. (2014). Wybrane aspekty zastosowania nanotechnologii w produkcji żywności. Żywność. Nauka. Technologia. Jakość, nr 5(96), 36-52.

Gozdowski D., Samborski S., Bobers E S. (2010). Evaluation of methods for detection of spacial outliners in the yield data of winter wheat. Colloquium Biometricum 40, 41-51.

Grisham T. (2009). The Delphi technique: a method for testing complex and multifaceted topics. International Journal of Managing Projects in Business Vol. 2 No. 1, 112-130

ILO, International Labour Office (1991). The Application of Modern Agricultural Technology: Sixth Item on the Agenda. Report of International Labour Conference, 78th Session, 1991, Geneva

Jensen H.G., Jacobsen L., Pedersen S. M., Tavella E. (2012). Socioeconomic impact of widespread adoption of precision farming in Denmark. Precision Agricutlure, 13, 661-667.

Kopiński J. (2014). Trendy zmian głównych kierunków produkcji zwierzęcej w Polsce w okresie członkostwa w UE. Prace naukowe UE we Wrocławiu, 361/2014, 117-129.

Kuzma, J., VerHage, P. (2006). Nanotechnology in Agriculture and Food Production: Anticipated Applications. Project on Emerging Nanotechnologies. Wilson Int. Center for Scholars, Washington, DC. Maciejczak M. (2017). Bioeconomy as a Complex Adaptive System of Sustainable Development. Journal of International Business Research and Marketing, Volume 2, Issue 2, 2017, 7-10

Ojha T., Misra S., Raghuwanshi N.S. (2015). Wireless sensor networks for agriculture: The state-of-theart in practice and future challenges. Computers and Electronics in Agriculture, 118 (2015), 66-84. Parisi C., Vigani M. and Rodríguez-Cerezo E. (2014). Proceedings of a workshop on "Nanotechnology for the agricultural sector: from research to the field". The Institute for Prospective Technological Studies (IPTS) of the European Commission's Joint Research Centre (JRC), Seville, Spain, 42-56. Parlińska M., Parliński J. (2011). Statystyczna analiza danych z Excelem. Wyd. SGGW, Warszawa Sanders K.T., Masri S.F. (2016). The energy-water agriculture nexus: the past, present and future of holistic resource management via remote sensing technologies. J. Cl. Prod. 117 (2016), 73-88.

Struik, P.C., Kuyper T.W., Brussaard L. and Leeuwis C. (2014). Deconstructing and unpacking scientific controversies in intensification and sustainability: Why the tensions in concepts and values? Current Opinion in Environmental Sustainability 8, 80-88.

Takacs-Gyorgy K., Lencsés E., Takacs I. (2013). Economic benefits of precision weed control and why its uptake is so slow. Studies in Agricultural Economics 2013, (1), 40-46.

Takacs-Gyorgy K., Rahoveanu T., Magdalena M., Takacs I. (2014). Sustainable New Agricultural Technology - Economic Aspects of Precision Crop Protection. Procedia Economics and Finance, Vol. 8, 2014, 729-736

Tittonell P. (2014). Ecological intensification of agriculture - sustainable by nature. Current Opinion in Environmental Sustainability, 8/2014, 53-61.

Tyler B. M., Griffin T. (2016). Defining the Barriers to Telematics for Precision Agriculture:

Connectivity Supply and Demand. Southern Agricultural Economics Association's 2016 Annual Meeting, San Antonio, Texas, February, 6-9 2016.

Weiss, M.D. (1996). Precision farming and spatial economic analysis: Research challenges and opportunities. American Journal of Agricultural Economics. 78(5), 1275-1280.

Xiweia Z. and Xiangdong Y., (2007). Science and technology policy reform and its impact on China's national innovation system. Technology in Society, Volume 29, Issue 3, August 2007, 317-325 